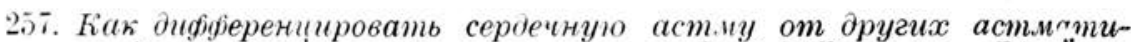
reских ирипаднов и каное применять .ечение. Prof. I. D o n a th (Die Ärztliche Praxis, ․․ 5, 1929. Medizinisches Seminar) огмечает случаи возможности легкого отграничения сердечной или легочной астмы от других видов удушья и вместе с тем случаи, где весьма трудно произвести таковое отграничение, гак, например, у стариков-эм физематиков с хроническим бронхитом и слабым сердеем у которых одышка является в результате как сердечного, так и легочного заболевания. В этих последних случаях с успехом применяются противобронхоастматические средства (астмолизин, лизостмин, белладонна и уод) одновременно с сердечными. При чисто сердечной астме морфий и его дериваты остаются лучшим средством. Так как в некоторых случаях невозможно установить отсутствие легочного компонента в этиологии данной астмы, а при чисто легочной астме морфий противопоказан,- следует всегда давать морфий в сочетании с коффеином или кардиазолем. Во многих случаях припадки купируются ин'екциями питуитрива, питуизана или питугляндоля в количестве от 0,5 до 1,0 см. $^{3}$, а также нитритами, теобромином, теоминалем. Случаи сердечной астмы, приводящие к явлениям сердечной недостаточности и отекам легких, подлежат кардиодиуретической терапии, причем самым лучпим и быстрым способом является внутривенное введение дигипурата в комбинации с эуфиллином или салирганом. С. М Райский.

258. Г'ипервентилячия легких как продилантическое мероприятие против пнев.нонии. Основываясь на работах Coryllos'a и Birnbaum'a, Scott'a и Cutler'a, что постоперационная пневмония развивается в ателектазированных участках легких, Henderson (A. М. А. 1929,9 II) рекомендует ингаляцию carbon dioxide в кислороде $(5,0-100,0)$, как наиболее эффективное ередство в предупреждении пневмонии как в послеоперационных случаях, так и при асфиксиях и инфекционных заболеваниях. Вследствие анәстезии дыхание становится поверхностным, отделы легких не вентилируются и появляется ателектаз, и инфекция этих отделов легко вызывает пневмонию; растяжение этих невентилируемых коллапсированных участков глубоким дыханием в результате ингаляции carbon dioxide препятствует ателектазу и предохраняет от развития пневмонии. H. Крамов.

259. S a p hir применил в 5 случаях брюпного тифа реакцило отнллонения ко.иn.е.иента (Wien. klin. Woch., 1929, ㅎ 33) и наблюдал превосходство этов реакции перед реакцией Wi dal'я в смысле чувствительности и более раннего. появления, почему она может служить весьма ценным лабораторным методом в диагностике брюшного тифа.

A. Вайнитейн.

\title{
2) Туберкулез.
}

260. E. Schw a $1 \mathrm{~m}$ говорит об опытах c Gerson'oвской диэтой nри легочнои туберкулезе (Kl. W. 1929, № 42). Втечение 1928 г. в Берлинском туберкулезном госпитале Schöneberg было лечено 20 легочных tbc б-ных по Gerson'y. Ни в одном случае ни аускультаторно, ни перкуторно, ни рентгенологически улучшений не получено. Только в одном случае исчезли tbc бациллы, но затем вскоре после выписки вновь появились. Увеличение веса получилось вовсех случаях, но не больпе, чем и при других методах лечения, причем важнейшим моментом здесь был Phosphorlebertran, так как в тех случаях, где он не давался, почти не было и прибавки веса. Автор указывает, что к отрицательвым результатам припли также $\mathrm{He}$ il net (Beitr. Klin. Tbc. 63,6), G m el in (lbidem, 66,4), W i ch$\mathrm{m}$ an $\mathrm{n}$ (Ibid. 66,4), Rit s chel (Ib. 68,3), Sch mitz (Z. Tbk. 47,6) Lies enfeld (Betr. Kl. Tbk. 72,3).

Здесь же следует отметить, что книжка Herrmannsdorfer'a о практич. применении диэты Gerson'a выпла в настоящее время 2-м изданием. Verl.Joh. Ambr. Barth. Leipzig. R M. 3. 20. HO.

261. D-r B. Gettkant, заведующий туберкулезной санаторией в IШӧнеберге, также касается легочного туберкулеза и Gers о п'овской диэть (D. m. W. 1929, 추 43). Наблюдая 20 тяжелых легочных tbc больных, Gettkant пришел к заключению, что ни в одном случае Gerson'oвская диәта не оказала. в.ияния на течение легочного ТБК: 11 человек из 20 умерли, 8 остались неработоспособными, процесс пел вперед и судьба 1 осталась неизвестной; при Gе s o n'овской диэте несомненно улучшение при lupus, при костном и суставном ТБК, но не при легочном. Как на большое затруднение при проведении диәты а. указывает на отсутствие соли: у ТБК б-ых итак аппетит плохой, а обессоленная пища, несмотря на ее самое лучпее приготовление, вызывает скоро отвращение и аппетит б-ых еще падает. 